\title{
FACTORS OF DIVERGENCE BETWEEN PERIPHERAL AND CENTRAL SUBREGIONS: THE CASE OF MAZOVIA PROVINCE, POLAND
}

\author{
TOMASZ ZABOROWSKI \\ ${ }^{1}$ Faculty of Geography and Regional Studies, University of Warsaw, Warsaw, Poland \\ Manuscript received: June 10, 2020 \\ Revised version: July 14, 2020
}

\begin{abstract}
ZавоRоWSкі T., 2020. Factors of divergence between peripheral and central subregions: The case of Mazovia province, Poland. Quaestiones Geographicae 39(4), Bogucki Wydawnictwo Naukowe, Poznań, pp. 39-51. 1 table, 6 figs.

ABSTRACT: The focus of this article is the study of centre-periphery intraregional development disparities using Poland's largest and most diversified Mazovia Province (Mazowieckie Voivodeship) as an example. The economic downfall of the Radom subregion, in comparison with the booming Warsaw agglomeration, clearly illustrates the polarisation of this province. A research question was if the location of the Radom subregion in Mazovia Province is a significant factor of its relative regression. In order to answer this question, selected development indicators of Mazovian subregions have been compared with their counterparts from surrounding provinces. Research results have shown that a subregion's location in a big and diversified province is a significant factor of intraregional centre-periphery development discrepancies.
\end{abstract}

KEYWORDS: disparities, administrative division, regional development, peripheries, Poland

Corresponding author: Tomasz Piotr Zaborowski, Faculty of Geography and Regional Studies, University of Warsaw, 00-927 Krakowskie Przedmieście 30, Warszawa, Poland; e-mail: t.zaborowski@uw.edu.pl

\section{Introduction}

\section{Centres vs. peripheries: Factors of growth and degradation}

The distinction between central and peripheral regions (Heffner, Gibas 2017) relates to their economic potential and socio-economic activity (Leszczewska 2010; Pawlas 2019). Central regions profit from a diversified set of favourable features such as good geopolitical location, well-developed hard and soft infrastructure, good access to well-educated labour as well as close proximity to capitals and metropolises (Leszczewska 2010). On the contrary, peripheral regions are those that suffer lack, deficiency or malfunctioning of these assets. There are clear disparities between well-developing central regions and their poor peripheral counterparts (Pawlas 2019). This fact, however, raises the questions if the rapid development of scarce centres is somehow related to poor performance of their peripheries and what circumstances may be acknowledged as factors of growth and collapse.

The main factor of a region's prosperity seems to be the performance of its urban centres. Thus, what are the features of cities being at the forefront of progress? Size (Śleszyński 2017), proximity to other centres (Śleszyński 2017) and administrative functions (Dascher 2000; Kisiała 2017; 
Szymańska 2013; Kaczmarek 1996; Liszewski, Maik 2000) are regarded as these features. A threat of losing socio-economic position imperils mainly distant and smaller towns (Śleszyński 2017). Contrarily, as some authors advocate, location of power and management institutions is a significant impact factor of concentration of people and attraction of further urban activities (Dascher 2000; Kisiała 2017). All these features of urban centres indirectly impact prosperity of their hinterlands. A question is, however, how far-reaching is this positive influence? There is evidence that distance is a factor of development diffusion (Heffner, Gibas 2017). Thus, the larger the region, the larger its peripheral zone is (Heffner, Gibas 2017). Larger regions are less congruent in all possible terms - spatially, economically, socially and in terms of infrastructure (Heffner, Gibas 2017). The distance from the region's capital is not compensated by its size either (Heffner, Gibas 2017).

\section{Development of Poland: Convergence or divergence?}

Since the 1989 political turn, Poland has encountered both international convergence and domestic interregional divergence. According to Martin (2005), 'global convergence - local divergence' (Krawczyk 2017: 86), is a development pattern specific not only to former communist countries, but also to the whole European Union (Krawczyk 2017; Sawicz 2013). The phenomenon, also called 'club convergence', is caused by the fact that richer regions grow quicker than poorer ones, and richer regions in relatively poorer countries grow quicker than richer regions in more affluent countries (Boldrin, Canova 2002; Sawicz 2013; Krawczyk 2017).

Irrespective of any assessment, there is a consensus that growth in Poland concentrates in the largest agglomerations (Lijewski 2003; Śleszyński 2007; Korcelli 2009; Sokołowski 2011; Czyż 2012; Heffner 2015; Zaborowski Ł. 2015, 2016). The effect of this phenomenon is a process of social and economic polarisation (Śleszyński 2017). A hypertrophy of settlement functions (Wyżnikiewicz 1997; Lijewski 2003) in selected agglomerations, accompanied by 'washing them out' from smaller centres (Korcelli 1999; Smętkowski 2007; Śleszyński 2009; Korcelli-Olejniczak 2012;
Owsiński, Śleszyński, 2016), may undermine Poland's historically established polycentric settlement pattern (Śleszyński 2017). Such a degradation may be observed in former capitals of Polish administrative provinces (voivodeships) that lost their status due to the reduction in the number of regions from 49 to 16 in 1999; hence, their condition is a common subject of research (Dziemianowicz 2000; Wilk 2004; Sokołowski 2006, 2011; Łukomska 2011, Komorowski 2012; Krysiński 2013, 2015; Szymańska 2015; Kurniewicz, Swianiewicz 2016; Kisiała 2017). Results of this research are ambiguous. Some indicate that the former capitals of regions have lost their development rank since 1999, in contrast to current capitals (Kisiała 2017), while the others claim the contrary (see Komorowski 2012; Kurniewicz, Swianiewicz 2016). Nonetheless, the regional capital status is claimed to be one of the factors of over-proportional social and economic growth of capital subregions (Spychała 2018). There are financial development mechanisms granting distribution privilege to central (Kisiała 2017) and regional administration, which may favour provincial capitals (Sokołowski 2006; Krysiński 2013, 2015).

The phenomenon of regional divergence (Berbeka 2006; Krawczyk 2017) in Poland has at least two scales. At the NUTS 2 level, referred to as 'regional' in Poland, distinct provinces (voivodeships) have developed differently, thus the development disparities between them have augmented (Węcławowicz et al. 2010; Krawczyk 2017). Simultaneously, at the NUTS 3 'subregional' level, inequalities have grown between metropolitan and peripheral areas (see e.g. Korenik 2008; Heffner 2009; Ehrlich et al. 2012; Kühn 2016; Malý 2016; Heffner, Gibas 2017). Vast peripheral zones may be observed especially in larger provinces, where a limited diffusion power of growth poles does not suffice to cover the whole region's area (Adamczyk-Łojewska 2011; Krawczyk 2017).

\section{Polarisation of Mazovia Province}

The outlined problem of polarisation is visibly present in the largest Polish Mazovia Province (in Polish województwo mazowieckie). It has a size of $35,558 \mathrm{~km}^{2}$ and a population of 5.32 million, among which 1.75 million inhabitants live 
in Warsaw, the capital city of Poland. Mazovia Province does not reflect other Polish provinces. With over 5 million people, it is larger than several EU states such as Croatia and Slovenia, and almost 5 times the size of the neighbouring Świętokrzyskie Province.

From 1 Jan 2018, the administrative Mazovia Province comprises two statistical NUTS 2 regions - the Warsaw metropolitan region (formed of three NUTS 3 subregions - the capital city of Warsaw and two surrounding hinterland ones, of Warsaw east and Warsaw west) and a doughnut-shaped compilation of other peripheral subregions of Płock, Ciechanów, Siedlce, Ostrołęka and Radom. ${ }^{1}$ All these peripheral subregions share common features related to their administrative position in Mazovia Province:

- their capital cities lost their status as the capital of a province as a result of the Polish administrative division reform in 1999.

- due to the large size of the province, the distance from all subregions' capital cities to the capital city of the region is long.

- all are located in the province that is simultaneously the country's capital, which triggers a significant disparity in both size and prominence of the province and subregions' capital cities.

Mazovia Province, being the largest one in the country, is the richest one at the same time. During the period 2007-2016, it had the fourth most rapid shift in wealth generation among all EU NUTS 2 regions (Eurostat 2018). The whole of Mazovia Province, as the first Polish region, reached the $75 \%$ level of the average GDP in the EU, and thus was excluded from some European regional aid programmes. Nevertheless, the reason for this extraordinary economic power is not the economic performance of the whole province, but the unusual concentration of money and resources in the capital city of Warsaw. As stated in The Strategy

1 The statistical division of Poland is as follows:

- NUTS 1 level comprises statistical macroregions formed of several administrative provinces (województwa [voivodeships]);

- NUTS 2 level comprises 15 out of 16 administrative provinces, except the biggest Mazovia Province that comprises two NUTS 2 entities;

- NUTS 3 level comprises statistical subregions formed of either one big city (e.g. Warsaw or Łódź) or a smaller city with its hinterland. of Development of Mazowieckie Voivodeship until 2030 (SRWM 2013), apparent good economic performance of the province largely depends on Warsaw's exceptional position considering important sales markets and a centre of administrative, management and political functions.

Notwithstanding the outlined extraordinary economic power of Mazovia Province, it suffers the biggest disparities too. It comprises both the richest Warsaw metropolitan area and the vast peripheral zones that are underprivileged and disproportionally weak in terms of human capital and production capacities (Śleszyński 2015). The scale of economic discrepancies is reflected in the unemployment rate in the region. In 2011, it amounted to $3.8 \%$ in Warsaw, whereas in the counties (poviats) of Szydłowiec and Radom, it was $37.2 \%$ and $29.9 \%$ respectively (SRWM 2013, 2.1, 2.3). Whereas GDP per capita in 2010 in Warsaw reached ca. $300 \%$ of the national average, in the Radom subregion, it amounted to only $75 \%$. The GDP per capita of the peripheral subregions of the province (the subregions of Ostrołęka, Siedlce and Radom) is similar to the GDP per capita in neighboring subregions located in regions classified as so-called 'Eastern Poland' that are subject to significant subsidies, because of their alleged poverty (GUS 2010). The Strategy of Development of Mazowieckie Voivodeship until 2030 assumes that the development would diffuse from Warsaw towards peripheral subregions (SRWM 2013). However, evidence shows that a diffusion of development incentives is limited to at most $40 \mathrm{~km}$ from the capital centre (Śleszyński 2015). Additionally, it is accompanied by an outflow of assets, mostly human ones, from peripheries (Śleszyński 2015). The large peripheral zone of Mazovia Province covers a majority of the region's doughnut, i.e. subregions of Ciechanów and Ostrołęka in the north, Siedlce in the east and Radom in the south (Heffner, Gibas 2017). All the above-mentioned towns are former provincial capitals that lost their status as a result of the 1999 administrative reform. They suffer various disadvantages, ranging from significant loss of functions to unfavourable social and economic conditions (Śleszyński 2017). These phenomena are typical to most of the administratively degraded post-provincial cities (Sokołowski 2006, 2014). The recent growth pattern of the province widens the development 
gap instead of alleviating it (GUS 2010). As the research of Rakowski (2011) shows, in the years 1999-2007, the differences have grown in the level of development between the Ostrołęka-Siedlce subregion and Warsaw. Rakowski's conclusion from this research is that the region's development strategy has not been implemented.

The most evident example of a degraded city is Radom, the second largest town in Mazovia Province (214,000 inhabitants). According to some research, Radom lost its economic functions to the largest extent, when compared to all Polish cities having more than 200,000 inhabitants (Śleszyński 2017). The GDP per capita of the Radom subregion, as a share of the province's average, had been falling since 2001, achieving $45.5 \%$ only in 2012, which was the smallest amongst all the Polish subregions. It is a symptom of Radom subregion's economic downfall in comparison to the richest, central subregion of Warsaw. One of the various reasons blamed for this situation is Radom's marginalisation in Mazovia Province (Sokołowski 2014) (Fig. 1).

\section{Research methods}

Based on the outlined premises, the following research questions arise:

- Are there any correlations between features of the analysed subregions that derive from the peripheral location in a province and the adopted development indicators?

- If so, are they stronger than correlations with other possible features of subregions?

In order to answer these questions, features of the analysed subregions related and not related to the peripheral location in a province have been identified as independent variables (IndVar). Then, their correlations with the adopted development indicators (dependent variables [DepVar]) have been measured.

The following features of the analysed subregions (IndVar), which are related to the peripheral location in a province, have been considered:

- provincial capital status of the subregion's largest city (IndVar 1),

\section{GfK Purchasing Power Poland 2016}

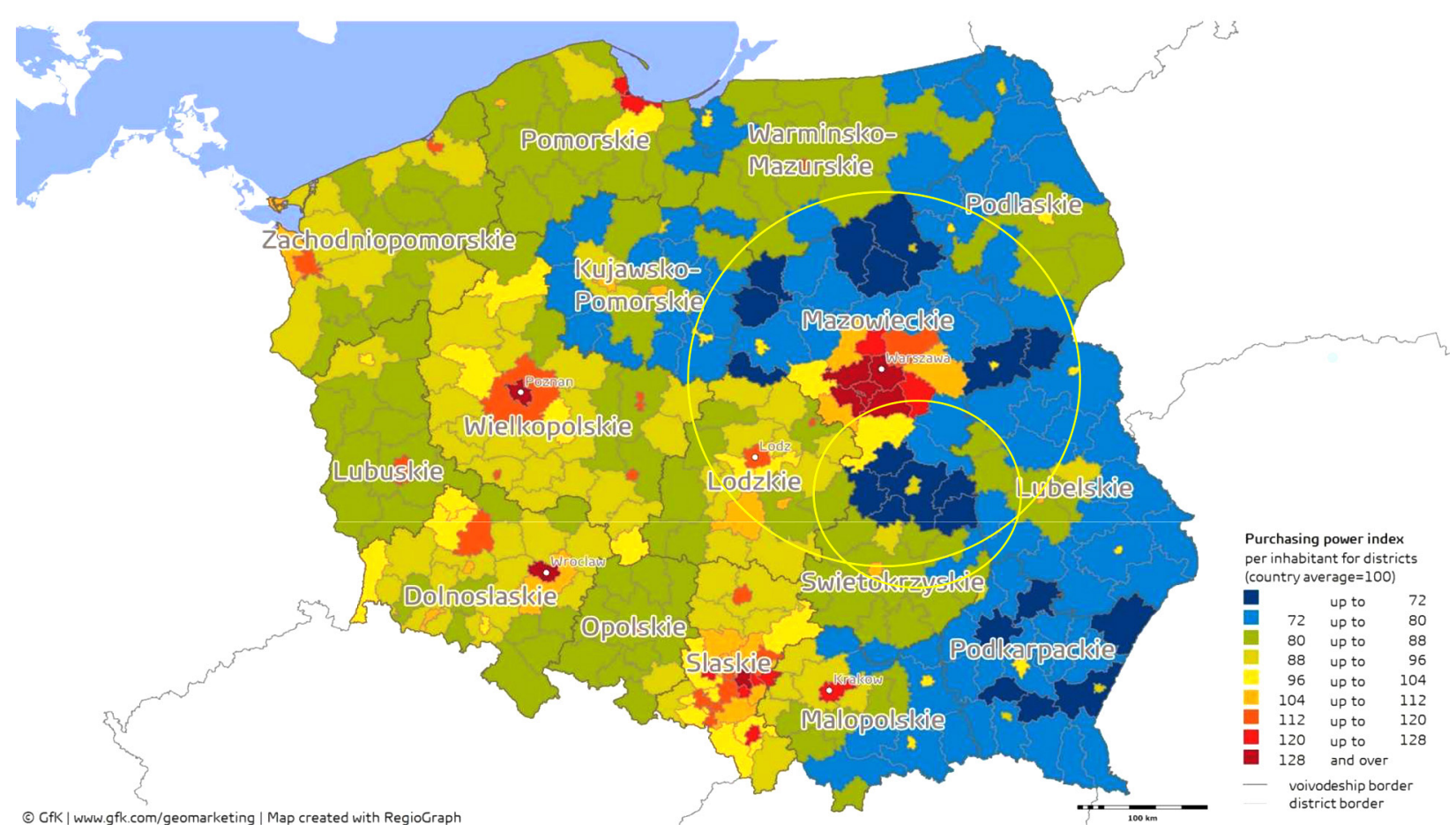

Fig. 1. Purchasing power of Polish subregions, 2016. Radom subregion and Mazovia Province are marked in yellow circles.

Source: GfK (2019), own elaboration. 
- level of centrality within the province (Cp) (IndVar 2) defined as

$$
C_{p}=\frac{S_{x}}{S_{c} \times d}
$$

where $S_{x}$ is the size of the subregion's largest city, $S_{c}$ is the size of the province capital and $d$ is the road distance between them (see Śleszyński 2015).

The following features that are not related to the subregions' peripheral location in a province have been considered:

- the size of the subregion's largest city (IndVar 3),

- the administrative status of the subregion's largest city (IndVar 4),

- the level of centrality within the country, measured as a distance between the subregion's and country's capitals (IndVar 5) (see Greenberg et al. 2018; Pawlas 2019).

Subregions' development levels in the years 2005 and 2015 (in some cases 2008 and 2016) have been taken into account because of data availability. The following features, deemed as development factors, have been considered:

- fixed assets in companies per capita,
- average salary as share of country's average,

- share of dwellings treated by sewage treatment plants,

- gas network per area,

- expenditure on environmental protection,

- number of beds in hospitals,

- neonatal fatalities per 1,000 births (an inhibitor),

- unemployment rate (an inhibitor),

- buildings completed per capita (for the years 2008 and 2016),

- dwellings completed per capita (for the years 2008 and 2016).

They have been aggregated into the following development indicators (DepVar):

- development levels for the years 2005 (2008) and 2015 (2016) (DepVar 1) (see Spychała 2018),

- absolute difference between the development levels in 2005 (2008) and 2015 (2016) (DepVar 2)

- relative difference between the development levels in 2005 (2008) and 2015 (2016) (DepVar 3) (see Kisiała 2017).

All subregions in Mazovia Province have been analysed (see below). As a reference, all subregions located in provinces neighbouring the

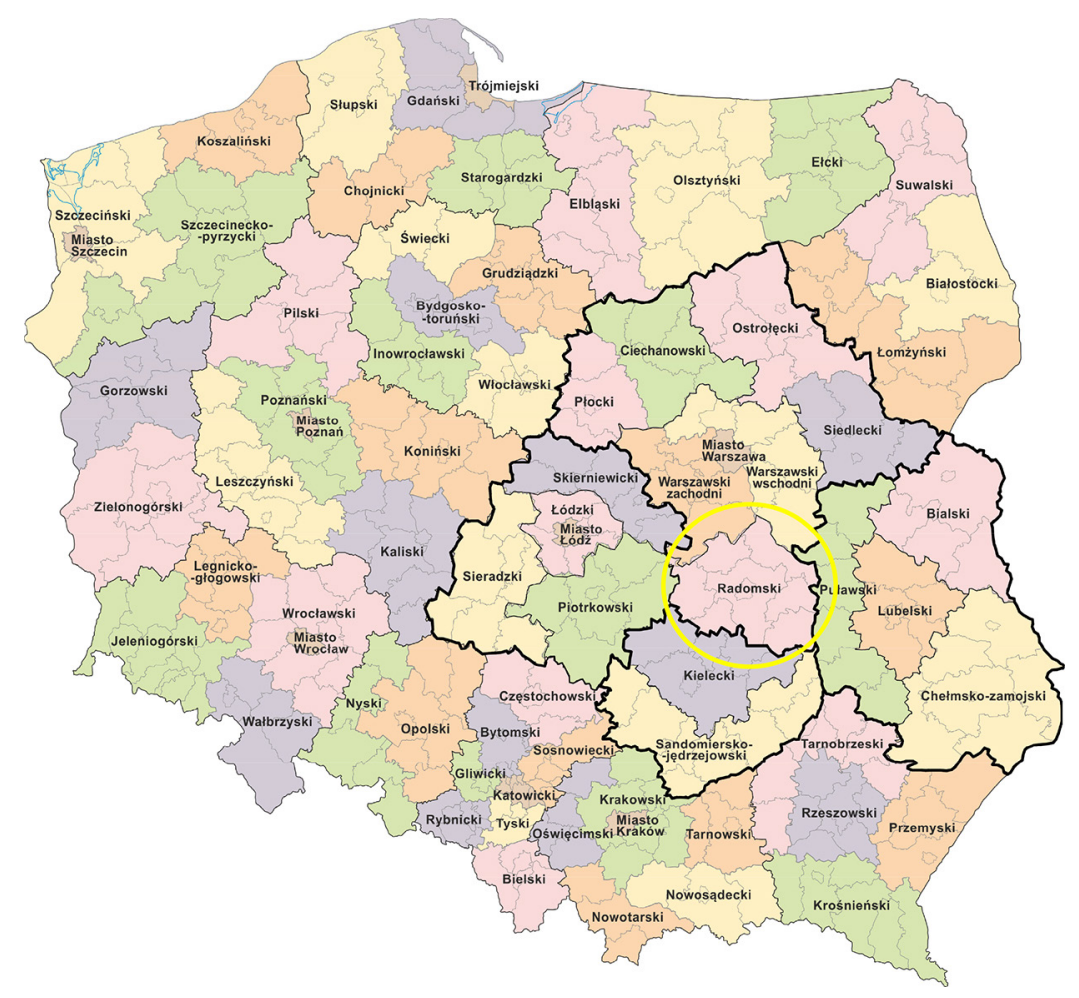

Fig. 2. Research area. Radom subregion is marked in a yellow circle. Source: own elaboration. 
Radom subregion have been considered, i.e. the provinces of Łódź, Świętokrzyskie and Lublin. Such a delimitation of reference area accounts for the subregions that differ in features deemed as possible development factors (IndVar); however, in many terms, they may be considered as similar to minimise the third variable problem (León, Montero 1997) (Fig. 2).

To maximise subregions' comparability, statistical NUTS 3 subregions were modified in a form close to functional city regions, perceived as a core city with its hinterland that exceeds boundaries of its urban agglomeration. It was needed because among statistical subregions, some are similar to functional city regions (e.g. subregions of Radom, Lublin and Kielce), some are doughnut shaped (e.g. the subregion of Łódź) and some are identical to big cities (Warsaw and Łódź).

In 2008, joint subregions of Ostrołęka and Siedlce (ostrołecko-siedlecki) as well as Ciechanów and Płock (ciechanowsko-płocki) were split. To reach comparability, they have been treated as joint subregions, as they were in 2005. All units developed in such a way that they have been uniformly called 'subregions' in this research. Figure 3 shows all the subregions considered.
As a method of assessment, The Pearson correlation coefficient was applied (see Spychała 2018):

$$
r_{x y}=\frac{n \sum x_{i} y_{i}-\sum x_{i} y_{i}}{\sqrt{n \sum x_{i}^{2}-\left(\sum x_{i}\right)^{2}} \sqrt{n \sum y_{i}^{2}-\left(\sum y_{i}\right)^{2}}}
$$

where $n$ is the number of subregions analysed $(\mathrm{n}=14), x$ is the value of each development factor (1-10), $y$ is the value of each independent variable (IndVar 1-5) and $i$ is the respective subregion.

To measure the desired correlation between independent (IndVar 1-5) and dependent (DepVar 1-3) variables, firstly the Pearson correlation coefficients between the values of each independent variable (IndVar 1-5) and the values of each development factor relevant to each of the dependent variables (DepVar 1-3) were calculated $\left(r_{\text {IndVar1Dep Var }} 1_{x y} \ldots r_{\text {IndVar5Dep Var }}{ }_{x y}\right)$. Secondly,

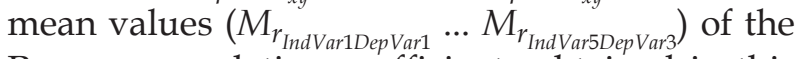
Pearson correlation coefficients obtained in this way were calculated for each pair of independent (IndVar 1-5) and dependent (DepVar 1-3) variables.

The following detailed research hypotheses (HD) have been formulated:

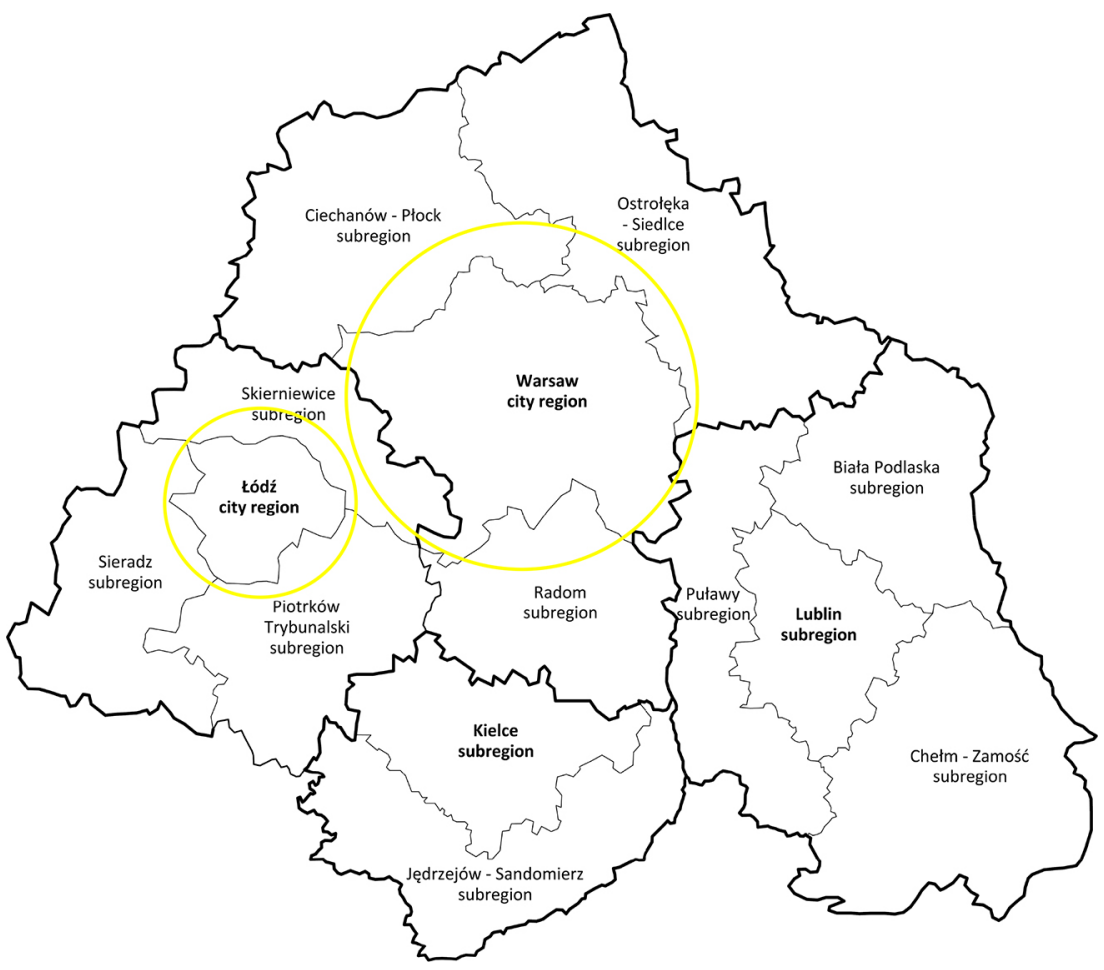

Fig. 3. Analysed subregions. The two city regions defined for this research are marked in yellow circles. Source: own elaboration. 
1. HD 1-3: The provincial capital status of the subregion's capital (IndVar 1) as well as subregion's level of centrality within the province (IndVar 2) are the positive factors of the following:

- development levels for the years 2005 (2006) and 2015 (2016) (DepVar 1) (HD 1),

- absolute difference between the development levels in 2005 (2006) and 2015 (2016) (DepVar 2) (HD 2), and

- relative difference between the development levels in 2005 (2006) and 2015 (2016) (DepVar 3) (HD 3).

2. HD 4-6: The provincial capital status of the subregion's biggest city (IndVar 1) is a more significant positive factor of DepVar 1 (HD 4), DepVar 2 (HD 5) and DepVar 3 (HD 6) than comparative factors (IndVar 3-5).

3. HD 7-9: Subregion's level of centrality within the province (IndVar 2) is a more significant factor of DepVar 1 (HD 7), DepVar 2 (HD 8) and DepVar 3 (HD 9) than comparative factors (IndVar 3-5).

\section{Results}

Table 1 depicts the calculated mean values of the Pearson correlation coefficients $M_{r_{\text {IndVar1Dep Var1 }}}$ ... $M_{r_{\text {IndVar5DepVar } 3}}$ that represent correlations between each of the independent (IndVar 1-5) and dependent (DepVar 1-3) variables.
As

$$
M_{r_{\text {IndVar1DepVar1 }}} \ldots M_{r_{\text {IndVar2DepVar3 }}}>0
$$

detailed hypotheses HD 1, HD 2 and HD 3 have been positively verified.

In order to better illustrate ranking of significance of subregions' features (IndVar) in terms of their correlation with respective dependent variables (DepVar), several graphs have been used (Figs 4-6). As can be seen in Fig. 4, it is the size of the subregion's largest city that mostly correlates with subregions' development levels for the years 2005 (2006) and 2015 (2016).

The research conducted here has shown that both the independent variables related to the subregions' peripheral location in a province, i.e. lack of the provincial capital status of the subregion's largest city (IndVar 1) and low level of centrality within the province (IndVar 2), are not as significant factors of subregions' development levels as the size (IndVar 3) and administrative status of their largest city (IndVar 4) (Fig. 4):

$$
\begin{aligned}
& M_{r_{\text {IndVar1DepVar } 1}}<M_{r_{\text {IndVar3DepVar1 } 1}} \\
& M_{r_{\text {IndVar2DepVar1 }}}<M_{r_{\text {IndVar3DepVar1 } 1}}
\end{aligned}
$$

This means that the detailed hypotheses HD 4 and HD 7 have been negatively verified.

As far as the absolute difference of development is concerned, Fig. 5 illustrates its correlation with the respective independent variables.

The ranking of correlations shows that the two most important factors that correlated with

\begin{tabular}{|c|c|c|c|c|}
\hline & & \multicolumn{3}{|c|}{$M_{r_{\text {IndVar1DepVar1 }}} \ldots M_{r_{\text {IndVar5DepVar } 3}}$} \\
\hline & & $\begin{array}{l}\text { Development lev- } \\
\text { els for years } 2005 \\
\text { and } 2015^{*}\end{array}$ & $\begin{array}{l}\text { Absolute differ- } \\
\text { ence in develop- } \\
\text { ment levels in } 2005 \\
\text { and } 2015^{*}\end{array}$ & $\begin{array}{c}\text { Relative difference } \\
\text { in development } \\
\text { levels in } 2005 \text { and } \\
2015^{*}\end{array}$ \\
\hline & & DepVar 1 & DepVar 2 & DepVar 3 \\
\hline Provincial capital status of largest city & IndVar 1 & 0.35 & 0.13 & 0.09 \\
\hline Level of centrality within province & IndVar 2 & 0.24 & 0.11 & 0.02 \\
\hline Size of largest city & IndVar 3 & 0.46 & 0.09 & 0.13 \\
\hline Administrative status of largest city & IndVar 4 & 0.37 & 0.09 & -0.02 \\
\hline Level of centrality in country & IndVar 5 & 0.34 & 0.01 & -0.08 \\
\hline
\end{tabular}
the absolute pace of subregions' development are

Table 1. Mean values of the Pearson correlation coefficients.

*2008 and 2016 respectively in specified cases.

Source: own elaboration. 


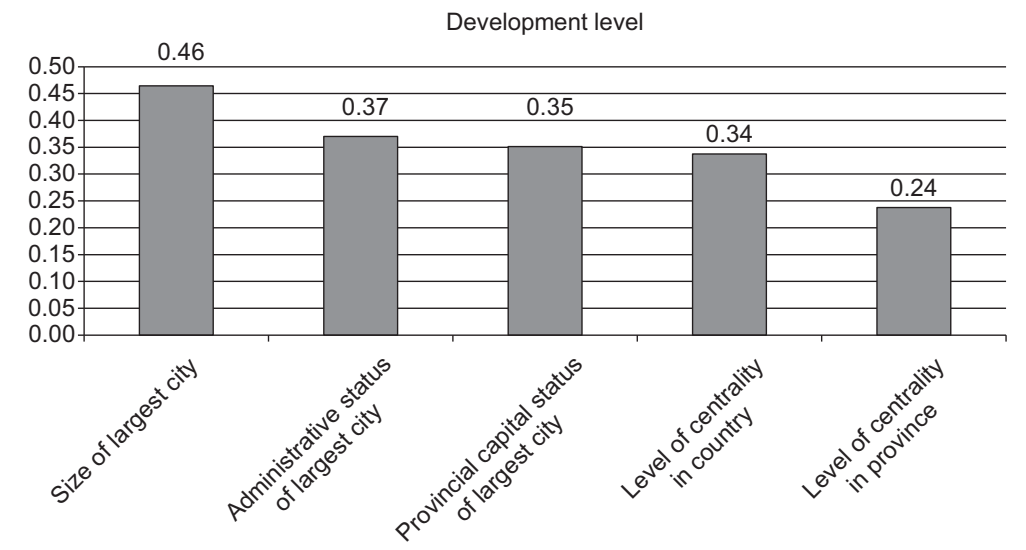

Fig. 4. Mean values of the Pearson correlation coefficients between independent variables and development levels for the years 2005 and 2015* (DepVar 1).

*2008 and 2016, respectively, in specified cases.

Source: own elaboration.

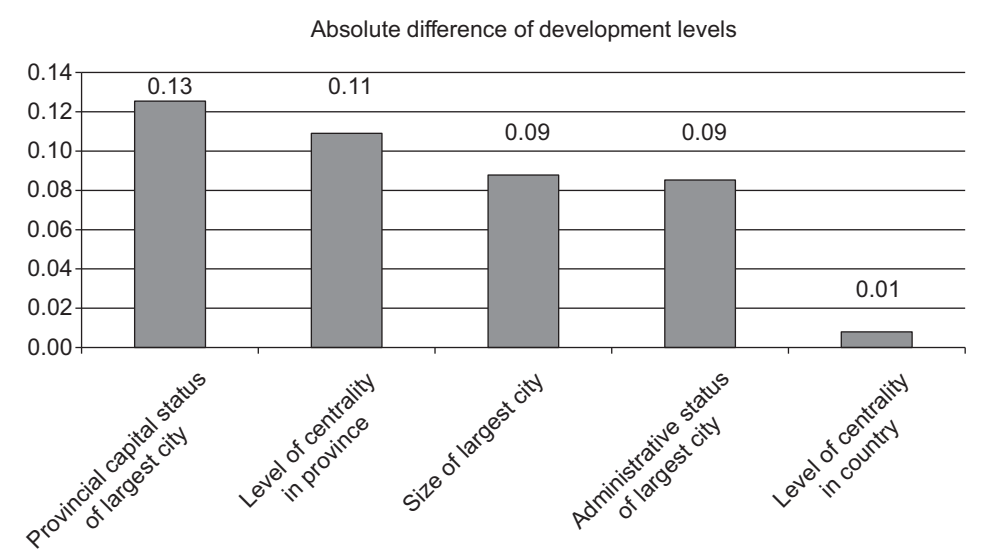

Fig. 5. Mean values of the Pearson correlation coefficients between independent variables and the absolute difference in development levels in the years 2005 and 2015* (DepVar 2).

*2008 and 2016, respectively, in specified cases.

Source: own elaboration.

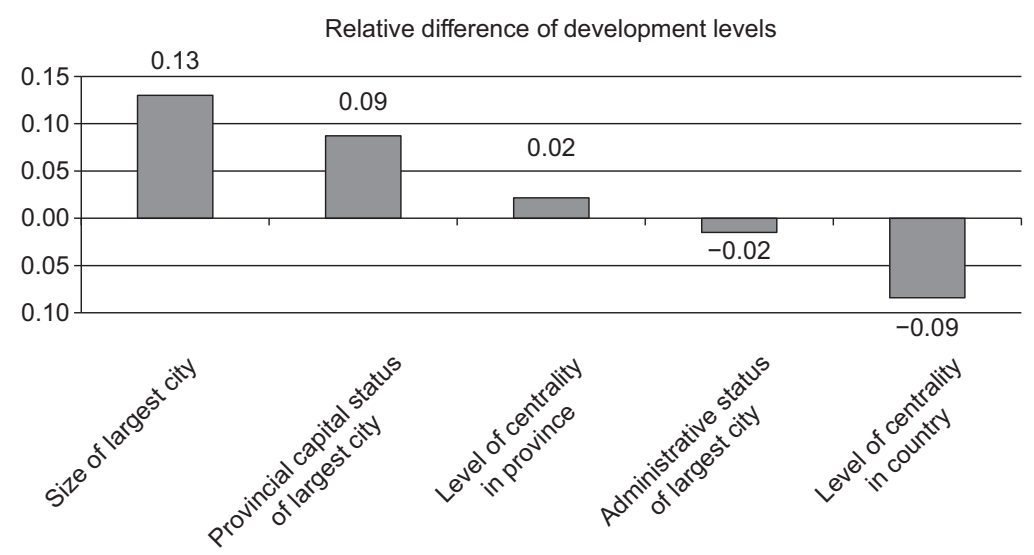

Fig. 6 Mean values of the Pearson correlation coefficients between independent variables and the relative difference in development levels in the years 2005 and 2015* (DepVar 3).

*2008 and 2016, respectively, in specified cases. 
the provincial capital status of the subregion's largest city (IndVar 1) and its level of centrality within the province (IndVar 2):

$$
\begin{aligned}
& M_{r_{\text {IndVar1DepVar2 }}}<M_{r_{\text {IndVar3DepVar2 }} \ldots M_{r_{\text {IndVar5DepVar2 }}}} \\
& M_{r_{\text {IndVar2DepVar1 }}}<M_{r_{\text {IndVar3DepVar2 }} \ldots M_{r_{\text {IndVar5DepVar2 }}}}
\end{aligned}
$$

This denotes that the detailed hypotheses HD 5 and HD 8 have been positively verified.

Other results can be seen in Figure 6 in the case of the correlation between independent variables and the relative difference in subregions' development levels in the years analysed.

The most important factor of alleviating existing disparities is the size of the subregion's largest city (IndVar 3):

$$
\begin{aligned}
& M_{r_{\text {IndVar1DepVar3 }}}<M_{r_{\text {IndVar3DepVar3 }}} \\
& M_{r_{\text {IndVar2DepVar3 }}}<M_{r_{\text {IndVar3DepVar3 }}}
\end{aligned}
$$

It implies negative verification of the detailed hypotheses HD 6 and HD 9.

\section{Conclusions}

The following conclusions may be drawn from the conducted research.

The provincial capital status of the subregion's largest city, as well as its high level of centrality within the province positively impact the performance of the subregion in terms of the development level and its dynamics (Table 1). In the case of peripheral subregions of Mazovia Province, it means that their location in this huge province and their capital cities' loss of the former provincial capital status are negative development factors. This conclusion supports the thesis, that above-mentioned two circumstances may be one of the reasons for the degradation of the Radom subregion that has been observed since its inclusion in Mazovia Province.

Figure 4 shows that all the surveyed features of the subregions, i.e. the size of a subregion's largest city, the administrative status of its largest city, its provincial capital status, the level of centrality within the country and the level of centrality within the province, are significant factors of the past and current subregions' level of development in recent years. However, the absolute level of subregions' development is mostly related to factors historically developed over time, such as the size or the overall administrative status of their largest cities.

Figure 5 shows the factors for the absolute rate of subregions' development in recent years. It indicates that the provincial capital status as well as the central location of the subregion within its province are the most significant development factors among all surveyed ones.

The interpretation of Figure 6 is more complicated. In terms of the relative rate of surveyed subregions' development in recent years, the most important factor is once again the size of their largest city. It means that the poor subregions which have big central cities are catching up quicker than the poor subregions with smaller cities. The second important and the only other significant factor in this regard is the provincial capital status of the subregion's largest city. It implies that the poor subregions of provincial capitals are catching up quicker than the poor subregions the largest cities of which are deprived of the provincial capital status.

Additionally, the development distance is reduced faster by the subregions located peripherally in the whole country, which may be explained by the 'Development of Eastern Poland' programme launched under the EU Cohesion Policy (Spychała 2018). This programme aims to support peripheral and poor eastern Poland regions (Czudec et al. 2019). What does it signify for the Radom subregion?

As the capital city of Radom is a considerably large subregional centre, the Radom subregion is privileged in terms of the relative rate of development. On the other hand, Radom's lack of provincial capital status as well as its central location in Poland inhibit the catch-up pace. Other Mazovian subregions share these two regrettable circumstances too.

Combining the results presented in Figures 5 and 6 , one can conclude that in the case of considerably affluent subregions, their further development is conditioned mainly by the provincial capital status of their largest cities as well as their central location within the province. Both features, by definition, are present in the subregions of provincial capitals. This fact detrimentally affects the pace of development of all peripheral 
Mazovian subregions in comparison to the provincial capital ones.

The reasoning presented allows answering the general research questions posed. Firstly, there are correlations between features of analysed subregions that derive from their peripheral location in a province and adopted development indicators in all terms, i.e. the development level and its absolute and relative pace. These correlations are stronger than all other presumable ones in the case of absolute development pace only. However, in other two measures, these two features are the second and third most important development factors, outdone by the feature of the size of the subregion's largest city only.

This research has supported the thesis that both the provincial capital status of the subregion's largest city as well as the subregion's central location within its province are important growth factors in contemporary Poland. In the case of the Radom subregion, it implies that Radom's loss of the provincial capital status in 1999 and its location in Poland's largest Mazovia Province, the capital city of which is also the capital of the country, may be deemed an important factor of its relative downfall ever since. This regrettable situation is shared by other former provincial capitals located in the analysed area too, especially those located in Mazovia Province.

\section{Discussion}

The main objective of The Strategy of Development of Mazowieckie Voivodeship until 2030 has been built on a paradox: 'territorial cohesion, perceived as lowering development disparities in Mazovia Province as well as growth of Warsaw Metropolitan Area's importance in Europe (...)' (SRWM 2013, 1). So, such an inconsistent definition of 'territorial cohesion' inevitably implies a dilemma: what should be the priority - growth of backward subregions or the prosperous Warsaw Metropolitan Area? A 'strategic goal' was formulated as follows: 'increase of region's competitiveness through growth of economic activity (...)' (SRWM 2013, 4). It should be implemented e.g. through the following ways: 'Warsaw as the capital city - growth and supplementing of metropolitan functions, supporting growth of regional and subregional centres'
(SRWM 2013, 4). Unfortunately, such a provision does not grant a higher priority to activities aimed at developing economically backward subregions, but treats them equally or even worse in comparison to the further strengthening of the Warsaw city region. The authors of the strategy explain such a choice by arguing that the Warsaw Metropolitan Area has 'the biggest potential of socio-economic development that has a vital impact on the growth of the whole region' (SRWM 2013, 6.2). This claim is disputable. Firstly, it seems rather that places with the greatest development potential are those that suffer economic downfall while having a demographic potential, unemployed labour force and material assets, e.g. the city of Radom. Secondly, significant disadvantage of peripheral Mazovian subregions towards the Warsaw Metropolitan Area denotes that promoted growth of the Warsaw city region does not pass on to province peripheries. As this research has proved, the grim reality of statistics clearly indicates that development diffusion model does not work in practice. The main dilemma of Mazovia Province is thus how to bind two types of areas, so that the economic success of Warsaw could be beneficial to the whole province (Śleszyński 2015).

The lack of desirable development priority of disadvantaged subregions discussed above reflects a delimitation of 'strategic intervention areas' set up in the strategy (SRWM 2013, 6). Because intervention measures are to be taken in order to change a poor condition, it could be assumed that a 'strategic intervention' would apply only to problem areas. Nonetheless, the strategy defines practically the whole province as 'strategic intervention areas'. It encompasses all peripheral subregions as well as the Warsaw Metropolitan Area, causing any 'strategic intervention' to be a fiction (Zaborowski T. 2013).

The current regional administrative division of Poland has been frequently criticised by scientists (Sokołowski 2014; Miszczuk 2003; Zaborowski Ł. 2009). It has been pointed out that the number and the form of regional territorial entities is an effect not only of a rational debate, but also of the pressure put by local communities, lobbies and political horse-trading (Nelicki 2001; Kowalczyk 2000; Wendt 2001; Miszczuk 2003; Piotrowski 2004; Bober et al. 2013; Zaborowski Ł. 2013). In effect, present administrative division does not suit 
any of the proposals made by scientists, being a combination of big and middle-sized regions' concepts (Miszczuk 2003; Zaborowski Ł. 2013, 2016). Therefore, many experts advocate a reform of the controversial division (Habuda, Habuda 2014; Honka 2014; Sokołowski 2014; Zaborowski Ł. 2014; Śleszyński 2015a).

\section{References}

Adamczyk-Łojewska G., 2011. Problemy konwergencji i dywergencji ekonomicznej na przykładzie krajów Unii Europejskiej, w tym Polski (Problems of economic convergence and divergence on examples of EU countries, i.a. Poland). Ekonomia 4(16). Wydawnictwo Uniwersytetu Ekonomicznego we Wrocławiu, Wrocław: 57-67.

Berbeka J., 2006. Konwergencja gospodarcza a konwergencja społeczna krajów Unii Europejskiej (15) w latach 19852002 (Economic vs. social convergence of EU countries in the years 1985-2002). Nierówności Społeczne a Wzrost Gospodarczy 8: 267-280.

Bober J., Hausner J., Izdebski J., Lachiewicz W., Mazur S., Nelicki A., Nowotarski B., Puzyna W., Surówka K., Zachariasz I., Zawicki M., 2013. Narastajace dysfunkcje, zasadnicze dylematy, konieczne dziatania. Raport o stanie samorzadności terytorialnej w Polsce (Growing disfunctionalities, principal dillemas, necessary action. A report on the state of territorial self-government in Poland). Uniwersytet Ekonomiczny, Małopolska Szkoła Administracji Publicznej, Krakow.

Boldrin M., Canova F., 2002. Inequality and convergence in Europe's regions: Reconsidering European regional policies. Economic Policy 16(32): 205-253.

Czudec A., Kata R., Wosiek M., 2019. Reducing the development gaps between regions in Poland with the use of European Union funds. Technological and Economic Development of Economy 25(3): 447-471.

Czyż T., 2012. Poziom rozwoju społeczno-gospodarczego Polski w ujęciu subregionalnym (The level of socio-economic development of Poland from a subregional perspective). Przeglad Geograficzny 84(2): 219-236.

Dascher K., 2000. Are politics and geography related?: Evidence from a cross-section of capital cities. Public Choice 105(3/4): 373-392.

Dziemianowicz W., 2000. Byłe stolice województw w rok po reformie, ekspertyza przygotowana na zlecenie Polskiej Agencji Rozwoju Regionalnego (Former capitals of voivodeships one year after the reform. An expertise ordered by the Polish Agency of Regional Development). Warsaw.

Ehrlich K., Kriszan A., Lang T., 2012. Urban development in Central and Eastern Europe - between peripheralization and centralization? disP - The Planning Review 48(2): 77-92.

Eurostat 2018. https://ec.europa.eu/eurostat/statistics-explained/index.php/GDP_at_regional_level\#Regional_gross_domestic_product_.28GDP.29_per_inhabitant (accessed: 21 September 2018).

GUS (Statistics Poland), 2010. Produkt krajowy brutto - rachunki regionalne w 2010 r. (GDP - regional accounts in 2010). www.stat.gov.pl/cps/rde/xbcr/gus/RN_pkb_rachunki_regionalne_2010_notatka.pdf (accessed: 30 December 2019).
GfK 2019. https://www.gfk.com/pl/aktualnosci/press-release/sila-nabywcza-mieszkancow-polski-per-capitawyniosla-6-366-euro-27-397-pln-w-2016-roku/ (accessed: 31 December 2019).

Greenberg Z., Farja Y., Gimmon E., 2018. Embeddedness and growth of small businesses in rural regions. Journal of $R u$ ral Studies 62: 174-182.

Habuda A., Habuda L., 2014. Zasadniczy podział terytorialny państwa. Między racjonalnym wyborem i grą zinstytucjonalizowanych interesów (The principal territorial division of the state. Between the rational choice and a game of institutionalised interests). Wroctawskie Studia Politologiczne 16: 24-41.

Heffner K., 2009. Aglomeracje średniej wielkości jako bieguny wzrostu i obszary strategicznej interwencji w regionach międzymetropolitalnych (Medium-sized agglomerations as growth poles and areas of strategic intervention in the inter-metropolitan regions). In: Makieła Z. (ed.), Potencjalne metropolie ze szczególnym uwzględnieniem Polski Wschodniej (Potential metropolises with an emphasis on Eastern Poland). Studia KPZK PAN 125: 10-17.

Heffner K., 2015. Lokalizacja instytucji publicznych jako element polityki miejskiej i regionalnej (The localization of public institutions as an element of urban and regional policies) In: Lokalizacja instytucji publicznych jako element polityki miejskiej i regionalnej (The localization of public institutions as an element of urban and regional policies). Biuro Analiz i Dokumentacji, Kancelaria Senatu, Warsaw: 3-25.

Heffner K., Gibas P., 2017. Centra regionów a spójność regionalna $\mathrm{w}$ Polsce (Centres of regions and regional coherence in Poland). Prace Naukowe Uniwersytetu Ekonomicznego we Wroctawiu 466: 98-110.

Honka Z., 2014. Is a new administrative division reform necessary? A voice in the discussion on self-government reform. Środkowoeuropejskie Studia Polityczne 3: 169-183.

Kaczmarek T., 1996. Rola funkcji administracyjnych w rozwoju średnich miast Wielkopolski (Gniezno, Kalisz, Konin, Leszno, Ostrów Wlkp., Piła) (The role of administrative functions in the development of medium-sized cities of Greater Poland (Gniezno, Kalisz, Konin, Leszno, Ostrów Wlkp., Piła)). Bogucki Wydawnictwo Naukowe, Poznań.

Kisiała W., 2017. Wpływ utraty statusu ośrodka wojewódzkiego na rozwój miast (The impact of the loss of province capital status on the development of cities). Research Papers of the Wroctaw University of Economics / Prace Naukowe Uniwersytetu Ekonomicznego we Wrocławiu 477: 117-126.

Komorowski J.W., 2012. Miasta wojewódzkie a miasta postwojewódzkie w Polsce - zróżnicowanie i zmiany poziomu gospodarczego w pierwszej dekadzie XXI wieku (Province capitals vs. former province capitals in Poland: Diversification and changes of the economic development levels in the first decade of 21st century). Studia Miejskie 8: 9-23.

Korcelli P., 1999. Warszawa i aglomeracja warszawska: tendencje, perspektywy, zagrożenia rozwoju (Warsaw and the Warsaw agglomeration: Tendencies, perspectives and risks of development). In Korcelli P. (ed.), Aglomeracje miejskie $w$ procesie transformacji, cz. III (Urban agglomerations in the proces of transformation, part 3). Zeszyty IGiPZ PAN 43: 5-18.

Korcelli P., 2009. System osadniczy Polski - tendencje i uwarunkowania przemian (The Polish settlement system: Tendencies and determinants of changes). In: Markowski T. (ed.), Koncepcja przestrzennego zagospodarowania kra- 
ju a wizje i perspektywy rozwoju przestrzennego Europy (The National Spatial Development Concept vs. visions and perspectives of the European spatial development). Studia KPZK PAN 122: 30-42.

Korcelli-Olejniczak E., 2012. Region metropolitalny - pojęcie, struktura przestrzenna, dynamika (Metropolitan region: The notion, spatial structure and dynamics). Prace Geograficzne IGiPZ PAN 235.

Korenik S., 2008. Kształtowanie się metropolii w warunkach polskich - ogólne uwagi (Shaping of metropolises in the Polish circumstances: General comments). In: Korenik S., Przybyła Z. (ed.), Gospodarka Przestrzenna, XI. Wydawnictwo UE we Wrocławiu, Wrocław: 155-161.

Kowalczyk A., 2000. Reforma podziału terytorialnego Polski w 1999 roku - krytyczna analiza mechanizmu jej wprowadzania (The reform of the Polish territorial division in 1999: A critical anlysis of its implementation technique). In: Ciok S., Ilnicki D. (ed.), Regionalny wymiar integracji europejskiej (The regional dimention of the European integration), Przeksztatcenia Regionalnych Struktur Funkcjonalno-Przestrzennych III(1). Instytut Geograficzny Uniwersytetu Wrocławskiego, Wrocław: 87-100.

Krawczyk G., 2017. Zróżnicowanie poziomu rozwoju ekonomicznego miast regionu wschodniego a zróżnicowanie dynamiki przemian (The diversification of the economic development levels of Eastern region cities and differentiation of dynamics of changes). Studia Regionalne $i$ Lokalne 4(70): 84-119.

Krysiński D., 2013. Wszystko co złe, to reforma. O utracie statusu miasta wojewódzkiego w dyskursie kaliszan (All that is wrong is the reform. The discourse of Kalisz citizens about the loss of the capital of a province status). Przegląd Socjologiczny 62(4): 25-42.

Krysiński D., 2015. Status wojewódzki miasta jako czynnik wzrostu w dobie postindustrialnej (City's capital of a province status as a factor of growth in postindustrial times). Acta Universitatis Lodziensis, Folia Sociologica 52: 27-44.

Kühn M., 2016. Peripherisierung und Stadt: Städtische Planungspolitiken gegen den Abstieg (The peripheralisation and the city: Urban planning policies against downfall). Transcript Verlag, Bielefeld.

Kurniewicz A., Swianiewicz P., 2016. Ból fantomowy czy realna strata? Wpływ utraty statusu stolicy województwa na rozwój gospodarczy i miejsce $w$ hierarchii systemu osadniczego (Phantom pain or a real loss? The impact of the loss of capital of a province status on the economic growth and the place in the settlement system hierarchy). Prace i Studia Geograficzne 61(2): 25-50.

León O.G., Montero I., 1997. Diseño de investigaciones. Introducción a la lógica de la investigación en Psicología y Educación (The design of the research. The introduction to the logic of the reaserch in the psychology and education). Segunda edición. MacGraw-Hill.

Leszczewska K., 2010. Aktywność ekonomiczna regionów peryferyjnych (Economic activity of peripheral regions). Nierówności Społeczne a Wzrost Gospodarczy 17: 215-225.

Lijewski T., 2003. Koncentracja ośrodków aktywności gospodarczej w Polsce w świetle list 500 firm (The concentration of centres of economic activity in Poland in the light of the 500 firms list). Przeglad Geograficzny 75(3): 433-447.

Liszewski S., Maik W., 2000. Wielka encyklopedia geografii świata, XIX:. Osadnictwo (The great encyclopedia of world's geography, 19th volume: The settlement). Wydawnictwo Kurpisz, Poznań.
Łukomska J., 2011. Byłe stolice województw 10 lat po reformie (Former capitals of provinces 10 years after the reform). In: Dziemianowicz W., Szlachta J., Szmigiel-Rawska K. (eds), Subregionalne bieguny wzrostu (Subregional growth poles). Uniwersytet Warszawski, Wydział Geografii i Studiów Regionalnych, Warsaw: 59-70.

Malý J., 2016. Impact of polycentric urban systems on intra-regional disparities: A micro-regional approach. European Planning Studies 24(1): 116-138.

Martin P., 2005. The geography of inequalities in Europe. Swedish Economic Policy Review 12: 83-108.

Miszczuk A., 2003. Regionalizacja administracyjna III Rzeczypospolitej. Koncepcje teoretyczne a rzeczywistość (The administrative regionalisation of the 3rd Republic. Concepts vs. reality). Wydawnictwo UMCS, Lublin.

Nelicki A., 2001. Kształtowanie się struktur administracji powiatowej i wojewódzkiej (The formation of structures of county and province administration). In: Gorzelak G., Jałowiecki B., Stec M. (eds), Reforma terytorialnej organizacji kraju: dwa lata doświadczeń (The reform of country's teritorial organization: Two years of experience). Scholar, Warsaw: 51-72.

Owsiński J.W., Śleszyński P., 2016. Modelling of the social, economic and spatial transformations in the Province of Masovia. Geographia Polonica 89(2): 251-257.

Pawlas I., 2019. Economic activity in peripheral regions - A case of Poland, Regional Formation and Development Studies 2(28): 99-115.

Piotrowski D., 2004. Rozwój peryferyjnego ośrodka o znaczeniu regionalnym a zmiany struktur funkcjonalno-przestrzennych na przykładzie Suwatk (The development of a peripheral centre of a regional significance and changes of spatio-functional structures on the example of Suwałki). Wyższa Szkoła Rozwoju Lokalnego, Żyrardów.

Rakowski W., 2011. Podregion ostrołęcko-siedlecki w idei zrównoważonego rozwoju woj. mazowieckiego (The subregion of Ostrołęka-Siedlce in the idea of sustainable development in Mazovia Province). Zeszyty Naukowe/ Wyższa Szkoła Ekonomiczno-Społeczna w Ostrołęce 8: 7-25.

Sawicz B., 2013. Konwergencja realna regionów Europy Środkowej i Wschodniej i Unii Europejskiej? (A real convergence of the regions of Central and Eastern Europe and European Union?) Biuletyn Europy Środkowej i Wschodniej - Puls Regionu 5. Centrum Stosunków Międzynarodowych, Fundacja Konrada Adenauera, Warszawa: 1-39.

Smętkowski M., 2007. Delimitacja obszarów metropolitalnych - nowe spojrzenie (The delimitation of metropolitan areas: A new insight). In: Gorzelak G., Tucholska A. (eds), Rozwój, region, przestrzeń (The development, region and space). Ministerstwo Rozwoju Regionalnego, EUROREG, Warsaw: 215-233.

Sokołowski D., 2006. Funkcje centralne i hierarchia funkcjonalna miast $w$ Polsce (Central functions and functional hierarchy of cities in Poland). Wydawnictwo Uniwersytetu Mikołaja Kopernika, Torun.

Sokołowski D., 2011. Centralność większych miast Polski. Rola czynnika administracyjnego i globalizacji (The centrality of larger Polish cities. The role of an administrative factor and globalisation). Przeksztatcenia regionalnych struktur funkcjonalno-przestrzennych 2. Instytut Geografii i Rozwoju Regionalnego, Uniwersytet Wrocławski, Wrocław: 11-24.

Sokołowski D., 2014. Niektóre uwarunkowania korekty podziału Polski na województwa (Some determinants of 
the amendment of the territorial division of Poland into provinces). Przegląd Geograficzny 86(4): 567-590.

Spychała M., 2018. Poziom rozwoju społeczno-gospodarczego powiatów w Polsce (The level of socio-economic development of Polish counties). Prace Naukowe Uniwersytetu Ekonomicznego we Wroctawiu/Research Papers of Wroctaw University of Economics 527: 242-254.

SRWM 2013. Uchwała nr 158/13 dnia 28 października 2013 roku w sprawie Strategii Rozwoju Województwa Mazowieckiego do 2030 roku (Resolution no. 158/13 of 28 October 2013 on The Strategy of Development of Mazowieckie Voivodeship until 2030).

Szymańska D., 2013. Geografia osadnictwa (The geography of settlement). Wydawnictwo Naukowe PWN, Warsaw.

Szymańska W., 2015. The role of the administrative functions in the development of the city in Poland (by example of degraded towns). In: Szymańska W. (ed.), Regional Development and Public Administration in the Context of General Tendencies of XXI century. Publishing House ADNDU, Słupsk-Kharkiw: 5-18.

Śleszyński P., 2007. Gospodarcze funkcje kontrolne w przestrzeni Polski (Economic control functions in the space of Poland). Prace Geograficzne IGiPZ PAN 213.

Śleszyński P., 2009. Dostępność metropolii jako warunek konkurencyjności polskiej przestrzeni (The access to metropolises as a condition of the competitiveness of Polish space). Mazowsze. Studia Regionalne 2: 53-71.

Śleszyński P., 2015. Obszar Metropolitalny Warszawy a rozwój Mazowsza. Wybrane wyniki badań prowadzonych w projekcie "Trendy Rozwojowe Mazowsza” (Warsaw Metropolitan Area and the development of Mazovia. Selected results of research done in the project of "Development trends of Mazovia"). Studia Regionalne $i$ Lokalne 3(61): 44-66.

Śleszyński P., 2015a. W sprawie optymalnego podziału terytorialnego Polski: zastosowanie analizy grawitacyjnej (The issue of an optimal territorial division of Poland: The application of gravitational analysis). Przeglad Geograficzny 87(2): 343-359.

Śleszyński P., 2017. Wyznaczenie i typologia miast średnich tracących funkcje społeczno-gospodarcze (The identification and typology of medium sized cities that lose their socio-economic functions). Przeglad Geograficzny 89(4): 565-593.

Tarschys D., 2003. Reinventing cohesion: The future of European structural policy, Report, 17. Swedish Institute for European Policy Studies, Stockholm.

Wendt J., 2001. Geografia władzy w Polsce (The geography of power in Poland). Wydawnictwo Uniwersytetu Gdańskiego, Gdańsk.

Węcławowicz G., Łotocka M., Baucz A., 2010. Rozwój miast $w$ Polsce (The development of cities in Poland). Raport wprowadzający Ministerstwa Rozwoju Regionalnego opracowany na potrzeby przygotowania przeglądu OECD krajowej polityki miejskiej w Polsce. Ministerstwo Rozwoju Regionalnego, Warsaw.

Wilk W., 2004. The effect of changes in administrative division on the economic position of the largest cities in Poland. Miscellanea Geographica 11: 241-247.

Wyżnikiewicz B., 1997. Regionalne zróżnicowanie siły ekonomicznej (na podstawie "Listy 500" największych przedsiębiorstw Gazety Bankowej) (Regional diversity of the economic power (on the basis of the 500 biggest companies of Gazeta Bankowa). In: Gorzelak G. (ed.), Przemiany polskiej przestrzeni (Changes of Polish space). Studia Regionalne i Lokalne 19(52). Europejski Instytut Rozwoju Regionalnego i Lokalnego Uniwersytetu Warszawskiego, Warsaw: 205-228.

Zaborowski Ł., 2009. Podział terytorialny Rzeczpospolitej spojrzenie krytyczne (The territorial division of the Republic of Poland: A critical insight). Prace Geograficzne 121. Uniwersytet Jagielloński, Krakow: 263-275.

Zaborowski Ł., 2013. Podziat kraju na województwa. Próba obiektywizacji (The division of the country into provinces. An attempt of an objectivization). Scholar, Warsaw.

Zaborowski Ł., 2014. Sieć ośrodków regionalnych w Koncepcji Przestrzennego Zagospodarowania Kraju 2030. Próba uporządkowania według czynników wielkości i odległości (The network of regional centres in the National Spatial Development Concept 2030. An attempt of arrangement on the factors of size and distance). Przeglad Geograficzny 86(4): 591-620.

Zaborowski Ł., 2015. Lokalizacja instytucji publicznych jako element polityki regionalnej i miejskiej (The localisation of public institutions as an element of regional and urban policy). In: Lokalizacja instytucji publicznych jako element polityki miejskiej i regionalnej (The localisation of public institutions as an element of urban and regional policy). Biuro Analiz i Dokumentacji, Kancelaria Senatu, Warsaw: 26-86.

Zaborowski Ł., 2016. Próba przebudowy układu województw z wykorzystaniem sieci ośrodków regionalnych (An attempt at a reconstruction of the system of provinces with an application of the regional centres network). Przeglad Geograficzny 88(2): 159-182.

Zaborowski T., 2013. Zrównoważony rozwój regionu czy dalszy wzrost dysproporcji? Komentarz do projektu Strategii Rozwoju Województwa Mazowieckiego do 2030 r. Innowacyjne Mazowsze (Sustainable development of the region or further growth of disparities? A comment of the draft of The Strategy of Development of Mazowieckie Voivodeship until 2030 "Innovative Mazovia”). Samorzad Terytorialny 11: 32-44. 